\title{
Implementasi Problem Based Learning dalam Mengoptimalkan Pembelajaran di Sekolah Luar Biasa Putera Asih Kediri
}

\author{
${ }^{1}$ Sufirmansyah, ${ }^{2}$ Laudria Nanda Prameswati \\ ${ }^{12}$ Institut Agama Islam Negeri (IAIN) Kediri \\ E-mail: imansyah28@iainkediri.ac.id
}

\begin{abstract}
This article aims to reveal the media and learning strategies at Sekolah Luar Biasa (SLB) Putera Asih Kediri. Education is something important for every Indonesian citizen. It does not distinguish between gender, ethnicity, race, culture, religion, even for children with special needs (Anak Berkebutuhan Khusus/ABK). However, the media and learning strategies used by the teacher in an extraordinary school (SLB) are certainly different from the teachers in public schools. This article was written according to a qualitative research that used a case study approach to reveal the implementation of PBL in SLB Putera Asih Kediri. This article conclude that every school needs creative teachers to use media and learning strategies. For this reason, it is expected that each young generation can utilize media and learning strategies that are appropriate to the needs of the students. PBL is very relevant with the needs of ABK in SLB because it can be combined with the teacheroriented study. PBL can be used as an alternative learning strategy to increase the understanding of ABK, so they can solve their daily problems.
\end{abstract}

Keywords: Children With Special Needs, Media, Learning Strategies, PBL.

\section{Pendahuluan}

Seorang pendidik dikatakan profesional apabila mampu menunjukkan empat indikator kompetensi dasar yang dipersyaratkan oleh undang-undang, yaitu kompetensi pedagogik, profesional, personal, serta sosial. ${ }^{1}$ Selain itu, pendidikan semestinya juga mempunyai kreatifitas dalam menentukan media dan strategi pembelajaran yang tepat untuk membantu peserta didik dalam memahami materi yang disampaikan. Terlebih lagi dalam Peraturan Pemerintah Nomor 19 Tahun 2005 tentang Standar Nasional Pendidikan Bab IV Pasal 19 ayat 1, dikatakan bahwa proses pembelajaran pada satuan pendidikan diselenggarakan secara interaktif, inspiratif, menyenangkan, menantang, memotivasi peserta didik untuk berpartisipasi aktif, dan memberikan ruang yang cukup bagi prakarsa, kreativitas, dan kemandirian sesuai dengan bakat, minat, dan perkembangan fisik serta psikologis peserta didik.

Proses pembelajaran bukan hanya dituntut untuk lebih menyenangkan sehingga pembelajaran lebih mudah diterima oleh peserta didik, tetapi juga harus mengutamakan fungsi dari pembelajaran tersebut. ${ }^{2}$ Saat ini, media pembelajaran sedang berada dalam puncak popularitas. Media sebagai sarana untuk membangkitkan daya pikir kritis peserta didik. Berbagai media dapat digunakan dalam proses pembelajaran, mulai dari media cetak hingga elektronik yang terkesan modern seperti proyektor LCD. Dengan

${ }^{1}$ Reni Fahdini dkk., "Identifikasi Kompetensi Guru sebagai Cerminan Profesionalisme Tenaga Pendidik di Kabupaten Sumedang," Mimbar Sekolah Dasar 1, no. 1 (2014): 33-42.

2 Tetema Telaumbanua, "Pemanfaatan Media Pembelajaran dalam Pembelajaran Bahasa Inggris," Warta Darmawangsa, no. 48 (2016): 42-50. 
menggunakan media pembelajaran, peserta didik akan mendapatkan pemahaman secara lebih efektif dan efisien. ${ }^{3}$

Namun, ternyata masih banyak sekolah yang tidak dapat membantu pemahaman peserta didik secara maksimal karena terbatasnya atau bahkan tidak ada media yang dapat digunakan. Sebab dengan adanya media yang diberikan oleh pendidik, pendidik akan sangat terbantu untuk menyampaikan isi materi pembelajaran kepada peserta didik jika dirasa bahwa materi yang didiskusikan termasuk materi yang sulit untuk dipahami.

Media dan teknologi pembelajaran berkaitan erat dengan meteri. Hal yang biasa jika media dan teknologi digunakan di sekolah umum. Namun, hal lain yang menjadi sorotan peneliti beberapa waktu ini adalah penggunaan media untuk peserta didik yang berada di Sekolah Luar Biasa (SLB) Putera Asih Kediri. Penggunaan media di Sekolah Luar Biasa tentunya berbeda dengan penggunaan media di sekolah umum.

Media dan strategi pembelajaran yang dipilih oleh pendidik seharusnya sudah mencakup pada materi yang hendak disampaikan oleh pendidik kepada peserta didik. Sebab hakikat dari media dan strategi pembelajaran adalah untuk membantu pendidik dalam menyampaikan materi sehingga peserta didik dapat dengan mudah menangkap isi dari materi. Hal ini menjadi kewajiban pendidik menemukan media dan strategi pembelajaran yang cocok untuk Anak Berkebutuhan Khusus (ABK).

Anak berkebutuhan khusus boleh saja disekolahkan di sekolah pada umumnya, yang nantinya akan menjadi konsep sekolah inklusif. Namun demikian, umumnya sekolah inklusi menghadapi berbagai permasalahan dalam menyelenggarakan pendidikan inklusi ini. ${ }^{4}$ Dengan kenyataan seperti itu, sebagian orang tua akan lebih memilih menyekolahkan anaknya di SLB daripada di sekolah umum. Tentu saja hal itu didasarkan pada pertimbangan bahwa anak mereka semestinya mendapatkan pelayanan yang prima.

Apabila pendidik di sebuah sekolah tidak menggunakan media dan teknologi pembelajaran yang tepat sebagai sarana untuk membantu mengasah kemampuan dan pemahaman peserta didik, maka pendidik akan menghadapi berbagai kendala dalam meningkatkan kualitas peserta didik. ${ }^{5}$ Terlebih lagi apabila sekolah tersebut merupakan SLB yang memberikan pelayanan pendidikan kepada anak berkebutuhan khusus.

Sepanjang pengamatan peneliti, SLB Putera Asih memiliki sarana-prasarana yang minim, sehingga media pembelajarannya pun juga terbatas. Selain itu, para pendidik pada umumnya melaksanakan proses pembelajaran secara normal, sesuai dengan kebutuhan peserta didik. Namun, terdapat fenomena unik dalam proses pembelajaran yang dilaksanakan di SLB Putera Asih Kediri. Para pendidik berani untuk mencoba menerapkan Problem Based Learning (PBL) sebagai strategi pembelajaran, guna meningkatkan pemahaman peserta didik terutama dalam hal mengatasi berbagai masalah yang dihadapi serta kegiatan-kegiatan yang dialami dalam kehidupan sehari-hari.

3 Ninda Handayani Muniroh Umar, Parmin Parmin, dan Indah Urwatin Wusqo, "Pengaruh Media Kartu Pintar Tumbuhan Berbasis Science Edutainment terhadap Minat Belajar dan Pemahaman Konsep Siswa Tema Gerak Tumbuhan,” Unnes Science Education Journal 5, no. 2 (2016): 1288-97.

${ }^{4}$ Nissa Tarnoto, "Permasalahan-Permasalahan yang Dihadapi Sekolah Penyelenggara Pendidikan Inklusi pada Tingkat SD,” Humanitas: Jurnal Psikologi Indonesia 13, no. 1 (2016): 50-61.

5 Sufirmansyah Sufirmansyah, "Reaktualisasi Kurikulum Pendidikan Agama Islam Integratif (Telaah Kritis Komparatif di Pesantren, Sekolah, Dan Madrasah)," Realita 6, no. 2 (2018): 157-68. 
Untuk mengungkap penerapan PBL dalam mengoptimalkan pembelajaran di SLB Putera Asih Kediri, peneliti menggunakan metode kualitatif berjenis studi kasus. Data dikumpulkan melalui srangkaian observasi dan wawancara dengan beberapa responden sebagai instrumen kunci. Data yang didapatkan kemudian diolah, direduksi, dan diinterpretasikan sesuai dengan kaidah penelitian kualitatif. Tidak hanya itu, triangulasi tetap dijadikan acuan dalam pengecekan keabsahan data. ${ }^{6}$ Dengan demikian, tujuan artikel ini akan dapat tercapai sehingga layak dijadikan referensi bagi peneliti lain yang akan melaksanakan penelitian sejenis di masa yang akan datang.

\section{Pembahasan}

\section{A. Sekilas tentang Media dan Strategi Pembelajaran}

Media digunakan sebagai salah satu alat bantu dalam meningkatkan kualitas pembelajaran. Karena dalam kegiatan tersebut, pendidik secara langsung dapat menampilkan apa saja yang akan disampaikan dan peserta didik dengan mudah dapat mengapresiasi sekaligus dapat menanyakan apa yang belum dipahami, sehingga terjadi feed back antara pendidik dengan peserta didik.

Bagi pendidik yang tidak menggunakan media dalam proses pembelajaran, pasti menemukan kesulitan ketika akan menyampaikan materi pembelajarannya. Pendidik yang tidak menayangkan materi pelajarannya secara visual, akan cenderung gagal dalam membangun atensi dari peserta didik untuk menyimak materi. Peserta didik pun akan terbatas dalam menyerap ilmu pengetahuan yang diberikan pendidiknya, dan terkesan anak sebagian ada yang bengong karena belum tahu materi yang disampaikan pendidiknya, karena tidak menampilkan contoh kongkretnya di lapangan.

Keberadaan iptek, akan semakin meningkatkan dalam peningkatan kualitas pembelajaran, sesuai dengan perkembangan dan tuntutan zaman. Sehingga akan terwujud kualitas yang baik. Selain itu, tugas bagi seorang pendidik harus dapat mengingkatkan kreatifitasnya dalam mengembangkan keterampilan proses manakala media yang ada belum tersedia dengan baik.

Ungkapan kata "media" berasal dari bahasa latin dan merupakan bentuk jamak dari kata medium secara harfiyah memiliki arti "perantara" atau pengantar. Menurut Education Association, media merupakan benda yang dimanipulasikan, dilihat, didengar, dibaca atau dibicarakan beserta instrumen yang dipergunakan dengan baik dalam kegiatan belajar mengajar, dapat mempengaruhi efektivitas program instruksional. ${ }^{7}$

Dengan adanya media akan membantu peserta didik dalam menerima materi yang dirasa sulit dan sukar dipahami. Begitu juga dengan pendidik, media pembelajaran juga membantu pendidik menyampaikan isi dari materi yang sulit kepada peserta didik. Manfaat dari penggunaan media pembelajaran, yaitu dapat

${ }^{6}$ Lexy J. Moleong, Metode Penelitian Kualitatif (Bandung: Remaja Rosdakarya, 2017).

7 Ahmad Zainuri, "Media Pembelajaran dalam Pandangan Islam," Medina-Te: Jurnal Studi Islam 14, no. 1 (16 Juli 2018): 4, https://doi.org/10.19109/medinate.v14i1.2351. 
menarik perhatian peserta didik, memudahkan peserta didik dalam memahami materi, serta sebagai bentuk pemanfaatan fasilitas secara optimal. ${ }^{8}$

Proses pembelajaran memuat lima komponen yaitu: pendidik (komunikator), bahan pembelajaran, media pembelajaran, peserta didik, dan tujuan pembelajaran. ${ }^{9}$ Dapat diartikan media pembelajaran adalah segala sesuatu yang dapat digunakan untuk menyalurkan pesan (materi pembelajaran) sehingga dapat merangsang pemikiran, minat, dan perhatian peserta didik dalam Kegiatan Belajar Mengajar untuk mencapai tujuan pembelajaran.

Media akan selalu terkait erat dengan strategi pembelajaran. Strategi (strategy) dalam dunia pendidikan diartikan sebagai a plan method or series activities designed to achieves a particular educational goal. ${ }^{10}$ Strategi pembelajaran adalah kegiatan yang dilakukan oleh pendidik dan peserta didik yang dipraktikkan di dalam kelas agar tercapai tujuan pembelajaran.

Strategi memiliki kemiripan, namun berbeda dengan metode (tharîqah), teknik (technique/shiyaghah), pendekatan (approach/ iqtirâb), siasat (siyâsah) atau taktik (tactic) mengajar. ${ }^{11}$ Strategi menunjuk pada sebuah perencanaan untuk mencapai sesuatu, sedangkan metode adalah cara yang dapat digunakan untuk melaksanakan strategi. Strategi adalah a plan of operation achieving something, sedangkan metode adalah a way in achieving something. Teknik dan taktik mengajar merupakan penjabaran dari metode pembelajaran. Teknik adalah kiat yang dilakukan untuk mengimplementasikan dan mengoperasionalkan suatu metode. ${ }^{12}$ Pengertian strategi bila dicermati mengandung dua hal penting yaitu: Pertama, strategi pembelajaran merupakan serangakaian rencana dalam mengajar serta memuat metode. Kedua, strategi disusun untuk mencapai tujuan yang jelas. ${ }^{13}$

Tujuan dari strategi pembelajaran sesuai dengan yang dipaparkan di atas. Tujuan dari Strategi pembelajaran dan media pembelajaran adalah untuk meningkatkan keefektifitas dalam pembelajaran. Untuk itu setiap pendidik harus terdorong menggunakan media dan strategi pembelajaran demi melancarkan proses belajar-mengajar.

Berdasarkan uraian di atas media dan strategi pembelajaran tidak terlepas dari peran pendidik. Sehingga dapat dikatakan bahwa media dan strategi adalah komunikasi antara pendidik dan peserta didik agar terwujud tujuan pembelajaran. Setiap pendidik pasti memiliki strategi dan media pembelajaran yang digunakan di dalam kelas. Hal ini digunakan untuk mendukung keberhasilan peserta didik dalam menyerap informasi yang telah dipaparkan oleh pendidik.

8 Telaumbanua, "Pemanfaatan Media Pembelajaran dalam Pembelajaran Bahasa Inggris."

9 Mochamad Desta Pradana, "Pengembangan Media Tutorial Mata Kuliah Media Fotografi Pembelajaran,” Edudeena 2, no. 1 (2018): 6.

${ }^{10}$ Jam'ah Abidin, "Rancangan Strategi Pembelajaran,” Jurnal Ilmiah Keislaman 12, no. 1 (2013): 2.

11 Ibid., 6.

12 Fipta Oktorina, "Peningkatan Prestasi Belajar Siswa Tuna Grahita Kelas Vi Slb Negeri Kota Bengkulu Semester I Tahun Pelajaran 2016/2017 Pada Pembelajaran Ips Melalui Penggunaan Media Gambar" 16, no. 1 (2017): 55.

13 Tuti Andriani, "Sistem Pembelajaran Berbasis Teknologi Informasi Dan Komunikasi," 2015, 46. 


\section{B. Pembelajaran di Sekolah Luar Biasa}

Dari segi bahasa (etimologi), pendidikan menurut Kurshid Ahmad yang dikutip oleh Abuddin Nata berasal dari bahasa Latin to ex (out) yang berarti keluar, dan ducere duc yang berarti mengatur, memimpin, mengarahkan (to lead). ${ }^{14}$ Dengan demikian secara harfiah pendidikan berarti mengumpulkan, menyampaikan informasi dan menyalurkan bakat; dan pada dasarnya pengertian pendidikan ini terkait dengan konsep penyampaian informasi dan pengembangan bakat yang tersembunyi.

Abuddin Nata memberikan definisi pendidikan merupakan proses atau usaha yang ditujukan untuk membina kualitas sumber daya manusia secara optimal. ${ }^{15}$ Sedangkan menurut Zamroni, tidak ada perbedaan antara setiap hak warga negara, tidak terkecuali anak berkebutuhan khusus. Sehingga pendidikan tidak memandang latar belakang budaya peserta didik. ${ }^{16}$

Hal ini telah ditegaskan dalam UUD 1945 pasal 31 UU No.20 tahun 2003 tentang sistem pendidikan nasional pasal 5 ayat 2 yang menyatakan bahwa "Warga negara yang memiliki kelainan fisik emosional, mental, intelektual, dan sosial berhak memiliki pendidikan khusus." Adanya UU pendidikan memberikan penekanan bahwa pendidikan harus dilaksanakan secara merata dan tanpa pengecualian.

Pendidikan Luar Biasa (PLB) adalah salah satu pendidikan yang diberikan kepada anak berkebutuhan khusus. Dengan terwujudnya Sekolah Luar Biasa sebagai wadah untuk anak berkebutuhan khusus mendapatkan pendidikan yang sama dengan anak lainnya.

Jika seorang anak pada umumnya menghabiskan waktu selama sepuluh jam per hari untuk berada di sekolah, maka hal itu tidak berlaku bagi anak berkebutuhan khusus. Mereka hanya menghabiskan waktu kurang lebih enam jam berada di sekolah. Dalam pencapaian tujuan pembelajaran yang diinginkan oleh pendidik bukan hanya kognitif saja tetapi juga menggali potensi-potensi yang tidak terlihat di dalam diri peserta didik.

Anak berkebutuhan khusus disekolahan di lembaga yang sesuai dengan kebutuhannya. Sebagai contoh, Sekolah Luar Biasa A untuk tunanetra, Sekolah Luar Biasa B untuk tunarungu, Sekolah Luar Biasa C untuk tunagrahita, Sekolah Luar Biasa D untuk tunadaksa, Sekolah Luar Biasa E untuk tunalaras, Sekolah Luar Biasa G untuk cacat ganda, dan lain sebagainya. Dengan adanya pengklasifikasian tersebut, diharapkan dapat membantu orang tua dalam menyekolahkan anak sesuai dengan kebutuhan. Tentunya, di setiap Sekolah Luar Biasa memiliki pendidik-pendidik profesional yang sudah disiapkan untuk

\footnotetext{
${ }^{14}$ Tarbiyah Dan, Keguruan Uin, dan Raden Fatah, "Implementasi Pendidikan Karakter Di Sekolah" 1 (2015): 4.

15 Zamrony, "Arah Baru Pendidikan Islam: Membangun Epistemologi,” t.t., 5.

16 Mohammad Muhassin, "Peranan Pendidikan Luar Biasa Dalam Pembinaan Anak Tunagrahita: Studi pada Sekolah Luar Biasa (SLB) C Dharma Bakti Pertiwi Bandar Lampung,” t.t., 2.
} 
memberikan pelayanan terbaik. Sehingga anak yang memiliki kebutuhan khusus tidak merasa terpuruk oleh keadaan.

Sebutan untuk anak berkebutuhan khusus biasanya diganti menjadi anak luar biasa, yang menandakan adanya kelainan khusus serta adanya potensi yang ada pada peserta didik yang berbeda dengan anak pada umumnya. Anak berkebutuhan khusus adalah anak yang memiliki karakteristik yang berbeda dengan anak lainnya. ${ }^{17}$ Anak berkebutuhan khusus memiliki kelainan menyimpang yang signifikan mulai dari mental, emosi, intelektual, atau fisik yang berbeda dari anak pada umumnya. ${ }^{18}$ Dalam penyajian materi yang diberikan, pendidik tentunya menggunakan media yang berbeda, sebab hambatan yang dilalui oleh peserta didik untuk proses penerimaan materi juga berbeda. ${ }^{19}$ Maksudnya, media pembelajaran yang digunakan harus disesuaikan dengan materi yang akan disampaikan. Dengan adanya hambatan yang terjadi dalam proses pembelajaran, pendidik akan mengupayakan agar hambatan yang ada dapat diminimalisir kemunculannya. Artinya, penggunaan media pembelajaran yang sesuai dengan kebutuhan dapat mengoptimalkan pemahaman peserta didik terhadap materi yang disampaikan.

\section{Media dan Strategi Pembelajaran di Sekolah Luar Biasa}

Jika setiap orang memiliki hak yang sama yaitu mendapatkan fasilitas yang layak sesuai dengan apa yang dibutuhkan maka perlu adanya koreksi dari pemikiran tersebut. Memang benar, penggunaan sarana prasarana yang sesuai dengan apa yang dibutuhkan oleh pendidik, maka isi dari materi dapat tersalurkan kepada peserta didik dengan baik. Namun, tidak menutup kemungkinan bahwa setiap sekolah memiliki fasilitas yang minim.

Pada dasarnya Sekolah Luar Biasa telah menyiapkan fasilitas yang sesuai dengan kebutuhan masing-masing anak. Tidak hanya masalah kurikulum saja yang disesuai dengan kebutuhan anak, tetapi juga desain kelas hingga letak kamar mandi pun memiliki penempatan yang khusus. Bahkan taman bermain juga harus diperhatikan untuk mengasah kemampuan anak. Tidak hanya itu dibentuknya taman bermain juga membantu anak untuk bersosialisasi dengan teman-temannya. Pengelolaan lokasi di Sekolah Luar Biasa sudah tertuliskan di Kepmen No. 486 tahun $1998 .{ }^{20}$ Jadi, seluruh bangunan dan tatanan fasilitas yang

${ }^{17}$ Ruliansyah Ruliansyah, Irfan Dwi Jaya, dan Septian Syaputra, “Aplikasi Pembelajaran Dasar Anak Retardasi Mental Berbasis Android (Studi Kasus: Sekolah Luar Biasa (SLB) C Karya Ibu Palembang)," JUSIFO (Jurnal Sistem Informasi) 3, no. 1 (30 Juni 2017): 5, https://doi.org/10.19109/jusifo.v3i1.3861.

18 Iman Winaldi dan Agus Setyawan, "Aplikasi Pengenalan Bahasa Isyarat Untuk Penyandang Tuna Tungu Berbasis Android (Studi Kasus: SLB Madina Serang)," JSiI (Jurnal Sistem Informasi) 5, no. 2 (18 Oktober 2018): 12, https://doi.org/10.30656/jsii.v5i2.779.

19 Oki Dermawan, "Strategi Pembelajaran Bagi Anak Berkebutuhan Khusus Di SLB,"

Psympathic: Jurnal Ilmiah Psikologi 6, no. 2 (28 Februari 2018): 886, https://doi.org/10.15575/psy.v6i2.2206.

20 Narulita Anugrahing Widi dan Rullan Nirwansyah, "Penerapan Aksesibilitas pada Desain Fasilitas Pendidikan Sekolah Luar Biasa” 2, no. 2 (2013): 4. 
ada di Sekolah Luar Biasa sudah menyesuaikan dengan yang ada di Kepmen No.486 tahun 1998.

Peneliti telah melakukan observasi di Sekolah Luar Biasa Putera Asih yang bertempat di Jalan Medang Kamulan No.1A, Balowerti, Kec.Kota Kediri, Jawa Timur 64129. Pada hari Senin, 16 Desember 2019 pukul 07.00 WIB sampai 09.00 WIB. SLB Putera Asih menyediakan tempat belajar untuk anak yang dikategorian sebagai tuna grahita dan tuna rungu. Terdiri dari Sekolah Dasar, Sekolah Menengah Pertama, dan Sekolah Menengah Kejuruan. Banyak hal yang didapatkan setelah berkunjung ke sekolah tersebut.

Pada dasarnya orang awam yang baru masuk ke lingkungan yang kebanyakan memiliki sedikit perbedaan dengan anak normal maka akan merasa takut jika peserta didik melakukan hal yang tidak diinginkan. Namun, semakin lama rasa takut itu akan hilang dan berubah menjadi rasa simpati dan rasa ingin tahu yang tinggi.

Peneliti melakukan wawancara dengan salah satu wali peserta didik. Beliau bernama Ibu Ida sebagai narasumber. Ibu Ida memiliki putri yang bernama Febri, usia sang putri lima belas tahun. Febri difonis oleh dokter yang berada di Rumah Sakit Ciwi Mojokerto mengalami tuna rungu pada usia tiga tahun. Tentunya sebagai Ibu sangat syok. Ketika di dalam kandungan, Febri tergolong bayi yang sehat seperti pada umumnya. Febri dan Ibu Ida mendapatkan komentar yang tidak mengenakkan. Sehingga Febri tidak ingin sekolah. Tetapi, Ibu Ida membujuknya untuk sekolah dan memberikan semangat kepada anaknya. Ibu Ida mendaftarkan Febri di Sekolah Luar Biasa Putera Asih.

Sekolah tersebut menjadi pilihan Ibu Ida karena melihat kondisi putrinya yang sama dengan peserta didik yang ada di Sekolah Luar Biasa Putera Asih. Untuk itu Ibu Ida berharap bahwa dengan menyekolahkan Febri di sekolah tersebut, Febri akan menjadi purti yang mandiri dan dapat dibanggakan oleh kedua orang tuanya meski ia memiliki kekurangan dengan sistem pendengaran.

Sekolah Luar Biasa Putera Asih memiliki cukup banyak peserta didik. Di setiap kelas hanya terdapat beberapa peserta didik saja antara empat sampai delapan peserta didik. Salah satu sorotan untuk peneliti adalah media pembelajaran yang diterapkan di Sekolah Luar Biasa Putera Asih. Karena memang setiap kelas hanya terdapat beberapa peserta didik jadi, ruang kelas yang dibutuhkan tidak terlalu besar. Bahkan satu ruangan diberi sekat untuk membedakan jenjang kelas.

Bapak Agus yang sedang mengisi di kelas empat Sekolah Dasar menyatakan bahwa untuk mengajar di sebuah Sekolah Luar Biasa harus memiliki kemampuan yang lebih daripada pendidik di sekolah umum. Sebab, tidak hanya menonjolkan keilmuan kognitif saja, tetapi juga cara berkomunikasi dengan peserta didik agar peserta didik paham dengan apa yang disampaikan.

Komunikasi antar pendidik dan peserta didik menjadi hal yang utama. Untuk itu pendidik yang ada di Sekolah Luar Biasa menggunakan gerak tubuh, mimik bibir, berhadapan langsung dengan peserta didik sehingga meminta 
peserta didik untuk melihat bentuk bibir, serta bantuan tangan yang dapat mendukung komunikasi tetap berjalan meski terdapat hambatan ketika pendidik menyampaikan materi dan peserta didik menerima materi.

Pembelajaran untuk anak berkebutuhan khusus tentu membutuhkan strategi yang berbeda sesuai dengan kebutuhan masing-masing peserta didik. Sehingga strategi pembelajaran yang paling tepat untuk digunakan di sekolah SLB adalah TCL (Teacher Centered Learning). Karena anak berkebutuhan khusus membutuhkan peran pendidik yang lebih dominan di dalam kelas. Jika tidak menggunakan Teacher Centered Learning peserta didik akan jauh lebih kesulitan dalam memahami materi. Fasilitas yang sesuai dengan permediknas tahun 2008 tentang sarana dan pra sarana SLB yang berkategori SLB B yaitu:

1. Ruang bina komunikasi dan persepsi bunyi dan irama.

2. Ruang bina persepsi bunyi dan bicara.

3. Ruang keterampilan. ${ }^{21}$

Media yang ada sangat minim, contohnya ketika melatih peserta didik untuk mengetik menggunakan laptop, hanya terdapat dua buah laptop yang dapat digunakan. Tentunya peserta didik harus dibagi menjadi dua kelompok. Setiap kelompok berisi empat peserta didik. Namun, tidak memutuskan semangat belajar peserta didik, peserta didik tetap mengikuti dan belajar mengetik secara bergantian dengan teman. Setiap kelas disediakan cermin berukuran sedang yang dapat digunakan untuk membantu mengolah kata peserta didik saat berbicara.

Ada panggung kecil di kelas empat yang digunakan sebagai tempat untuk peserta didik belajar mata pelajaran seni budaya dengan tema tari. Sehingga setiap hari Kamis dan Jumat bergantian untuk memakai panggung tersebut. Panggung juga dilengkapi dengan cermin sehingga peserta didik dapat mengamati pantulan gerakan tari.

Meski media yang ada sangat minim, semangat peserta didik untuk belajar tidak pernah luntur, terbukti bahwa setiap hari peserta didik tetap hadir di sekolah dengan penampilan yang sopan dan rapi. Begitu juga dengan pendidik-pendidik yang ada di sekolah tanpa bosan membantu peserta didik untuk mencari potensi yang ada pada peserta didik. Hal ini tidak diragukan lagi bahwa setiap peserta didik sudah memiliki peningkatan.

Untuk peserta didik yang duduk dibangku Sekolah Menengah Kejuruan, tidak memiliki halangan sehingga memiliki keterampilan yang sama dengan anak normal. Terdapat keahlian, memotong rambut, menjahit baju, dan merias. Dengan keterampilan yang dimiliki, pendidik berharap peserta didik dapat menemukan potensi yang ada pada dirinya. Sehingga peserta didik tampil dengan percaya diri jika dibandingkan dengan anak normal.

${ }^{21}$ Muhassin, "Peranan Pendidikan Luar Biasa Dalam Pembinaan Anak Tunagrahita: Studi pada Sekolah Luar Biasa (SLB) C Dharma Bakti Pertiwi Bandar Lampung,” 7. 
Sarana dan prasarana yang disediakan sekolah terbilang cukup memadai. Terbukti dari ruang kelas yang nyaman, kursi dan meja layak digunakan, alat cukur, make up rias, alat jahit, semua dapat digunakan oleh peserta didik. Maka dari itu peserta didik yang memiliki kekurangan, juga memiliki banyak kelebihan yang bisa saja anak normal tidak memilikinya. Sebenarnya tidak ada perbedaan anatara anak normal dan anak berkebutuhan khusus. Setiap anak terlahir dengan fitrah yang suci, memiliki takdir, memiliki kemampuan dan kelemahan. Hanya saja yang membedakan adalah bagaimana cara setiap anak tetap semangat untuk memotivasi diri sehingga menciptakan kualitas unggul serta tindakan tekat untuk melakukan hal-hal positif sehingga terwujud peserta didik yang diharapkan oleh bangsa Indonesia sesuai dengan Undang-Undang no.20 tahun 2003 pasal 3 yang berbunyi:

"Pendidikan nasional berfungsi mengembangkan kemampuan dan membentuk watak serta peradaban bangsa yang bermartabat dalam rangka mencerdaskan kehidupan bangsa, bertujuan untuk berkembangnya potensi peserta didik agar menjadi manusia yang beriman dan bertaqwa kepada Tuhan Yang Maha Esa, berakhlak mulia, sehat, berilmu, cakap, kreatif, mandiri, dan menjadi warga negara yang demokratis serta bertanggung jawab.”

Untuk itu strategi pembelajaran dan media pembelajaran yang dapat diterapkan di Sekolah Luar Biasa Putera Asih yang menyediakan pendidikan untuk Anak Berkebutuhan Khusus (ABK) tunagrahita dan tunarungu adalah strategi pembelajaran Problem Based Learning. Di mana jenis strategi ini selain dapat diterapkan di sekolah umum, juga dapat diterapkan pada Anak Bekebutuhan Khusus (ABK) karena mengasah kemampuan berpikir anak.

Memang, Anak Berkebutuhan Khusus (ABK) sangat membutuhkan peran pendidik. Hal ini tidak menutup kemungkinan bahwa pendidik dapat menciptakan strategi pembelajaran yang lebih menarik. Bahkan peserta didik pun juga ingin merasakan pembelajaran yang sedikit berbeda dari sebelumnya.

\section{Optimalisasi Pembelajaran di SLB melalui Strategi Problem Based Learning}

Strategi pembelajaran Problem Based Learning (PBL) merupakan strategi pembelajaran yang berpusat pada peserta didik. Dalam strategi ini peserta didik diminta untuk memecahkan masalah yang diberikan oleh pendidik. ${ }^{22}$ Biasanya, masalah yang diberikan oleh pendidik sesuai dengan kehidupan sehari-hari atau sebuah masalah yang sekarang ini sedang marak diperbincangkan. Peserta didik berfokus pada pemecahan masalah, sehingga peserta didik diberikan tanggungjawab untuk menganalisa, mengindentifikasi sesuai dengan kemampuan peserta didik. Peran pendidik dalam strategi ini sebagai pendukung dan

${ }^{22}$ Ruliansyah, Jaya, dan Syaputra, “Aplikasi Pembelajaran Dasar Anak Retardasi Mental Berbasis Android (Studi Kasus," 56. 
memberikan bimbingan kepada peserta didik. ${ }^{23}$ Pembelajaran berbasis masalah membantu peserta didik untuk meningkatkan kemampuan berpikir secara terbuka dan terstruktur. Peserta didik pun dipersilakan untuk menemukan solusi dari masalah yang diberikan. ${ }^{24}$

Melalui strategi ini peserta didik tidak hanya sekadar mendengarkan, mencatat, dan menghafalkan materi, tetapi peserta didik juga berpikir kritis, berkomunikasi, mencari jawaban atas masalah yang diberikan sampai akhirnya menyimpulkan jawaban. Dengan ini materi yang diterima akan lebih mudah tertanam di dalam pikiran peserta didik.

Secara historis, Problem-Based Learning (PBL) ini dikembangkan oleh para pakar pendidikan Barat, di antaranya adalah Gagne, yang menyusun sistematika jenis belajar yang dikenal dengan delapan tipe belajar, yaitu 1) signal learning, 2) stimulus-signal learning, 3) cabingin learning, 4) verbal association, 5) discrimination learning, 6) concept learning, 7) rule learning, dan 8) problema solving. Delapan tipe belajar tesebut disusun secara hirarki yang dalam pelaksanaannya harus berurutan. ${ }^{25}$

Problem-Based Learning (PBL) didasarkan pada penelitian yang dilakukan oleh Barrow dan Tamblyn dan diimplementasikan pertama di sekolah kedokteran di Universitas Kanada pada tahun 60-an. ${ }^{26}$ Barrow mendefinisikan PBM sebagai "The learning that results from the process of working towards the understanding of a resolution of a problem. The problem is encountered first in the learning process." ${ }^{27}$ Jadi, PBL atau PBM mengusungkan masalah sesuai dengan kehidupan yang ada pada peserta didik sehingga peserta didik dapat menerapkannya di dalam kehidupan sehari-hari.

Tokoh lain yang mengembangkan strategi pembelajaran Problem Based Learning (PBL) adalah John Dewey seorang peneliti berasal dari Amerika yang terkenal dengan sistem proyek atau metode pemecahan masalah. Gagasan John Dewey bertumpu pada dua aspek yaitu: 1) Memikirkan usia peserta didik sehingga akan mengerti kemampuan peserta didik, mulai dari cara berfikir dan cara kerjanya, dan 2) Mengetahui tujuan dari pembelajaran. Sedangkan ciri-ciri dari Problem Based Learning (PBL) adalah:

1. Problem Based Learning (PBL) merupakan rangkaian dari aktivitas. Artinya, dalam penerapannya tentu akan menimbulkan kegiatan-kegiatan yang saling berkaitan.

2. Peserta didik diberikan permasalahan yang sesuai dengan usia.

${ }^{23}$ Ahmad Syaifulloh, "Pengaruh Strategi Problem-Based Learning (PBL) Terhadap Motivasi Dan Hasil Belajar Peserta Didik Pada Mata Pelajaran Fiqih Di Ma. Khozinatul "Ulum Blora Jawa Tengah," Wahana Akademika: Jurnal Studi Islam dan Sosial 3, no. 2 (28 Desember 2016): 123, https://doi.org/10.21580/wa.v3i2.1148.

24 Tatang Herman, "Pembelajaran Berbasis Masalah untuk Meningkatkan Kemampuan Berpikir Matematis Tingkat Tinggi Siswa Sekolah Menengah Pertama," 2007, 16.

25 M.Taufik Amir, Inovasi Pendidikan Melalui Problem Based Learning Bagaimana Pendidikan Memberdayakan Pemelajar di Era Pengetahuan (Jakarta: Kencana, 2009), 209.

${ }^{26}$ Dindin Abdul Muiz Lidinillah, "Pembelajaran Berbasis Masalah (Problem Based Learning)," Jurnal Edukasi: Jurnal Bimbingan Konseling 1, no. 2 (2010): 6.

27 Ibid., 7. 
3. Pemecahan masalah dilakukan melalui pendekatan ilmiah (scientific). Berpikir menggunakan pendekatan ilmiah adalah berpikir secara deduktif dan induktif. Proses berpikir ini dilakukan secara sistematis atau berurutan. ${ }^{28}$

Problem Based Learning (PBL) membawa sebuah perubahan dari tradisi pembelajaran yang berasal dari pendidik atau pendidik sebagai satu-satunya sumber belajar peserta didik menjadi peserta didik diberikan permasalahan terlebih dahulu sehingga peserta didik dapat menemukan identifikasi masalah serta memecahkan masalah hingga menemukan solusi untuk menyelesaikan masalah yang didapatkan. ${ }^{29}$

Peneliti mengangkat strategi pembelajaran Problem Based Learning dapat diterapkan di Sekolah Luar Biasa khususnya di SLB Putera Asih Kediri sebab selain peserta didik mendapatkan inovasi baru dalam pembelajaran, peserta didik juga akan mendapatkan pengalaman dalam memecahkan masalah yang sebelumnya belum pernah didapatkan selama peserta didik berada di sekolah tersebut.

Beberapa kelebihan strategi pembelajaran Problem Based Learning yaitu dapat mengasah kemampuan berpikir peserta didik, memungkinkan terjadinya aaktivitas secara kelompok atau individu, melatih peserta didik untuk memecahkan masalah, serta memungkinkan peserta didik untuk mengungkapkan pemikirannya. Sementara itu, kelemahan PBL yaitu tidak dapat menyediakan sumber belajar secara lengkap, berpotensi memunculkan ketidakcocokan antar sesama teman dalam berkelompok, membutuhkan waktu yang lama, serta dinilai lebih cocok untuk jenjang SMA dan pendidikan Tinggi. ${ }^{30}$

Tentunya penerapan Problem Based Learning (PBL) yang diterapkan di Sekolah Luar Biasa (SLB) berbeda kapasitas atau bobotnya saat diterapkan di sekolah umum. Seharusnya lebih ringan dan lebih mudah dipahami oleh peserta didik. Ketika di sekolah umum peserta didik dapat secara mandiri mengklasifikasikan masalah yang diberikan dan peran pendidik hanya sebagai pengamat kinerja peserta didik. Namun, tidak untuk peserta didik yang ada di Sekolah Luar Biasa (SLB) pastinya membutuhkan peran pendidik untuk membantu memecahkan masalah yang diberikan. Problem Based Learning (PBL) yang akan diterapkan di Sekolah Luar Biasa (SLB) tidak murni hanya membutuhkan peran peserta didik saja, tetapi juga membutuhkan peran pendidik. Dikhawatirkan jika peserta didik dibiarkan tanpa pengarahan dari pendidik justeru akan menimbulkan masalah-masalah baru atau bahkan peserta didik akan bermain dengan teman-teman.

${ }^{28}$ Wina Sanjaya, Strategi Pembelajaran Berorientasi Standart Proses Pendidikan (Jakarta: Prenada Media Group, 2010), 214.

${ }^{29}$ D A Kilroy, "Problem Based Learning," Emergency Medicine Journal 21, no. 4 (1 Juli 2004): 414, https://doi.org/10.1136/emj.2003.012435.

30 Sudarman, "Problem Based Learning : Suatu Model Pembelajaran untuk Mengembangkan dan Meningkatkan Kemampuan Memecahkan masalah," Jurnal Pendidikan Inovatif 2, no. 2 (t.t.): 6. 
Menurut peneliti, peserta didik di setiap kelas di Sekolah Luar Biasa (SLB) tidak terlalu banyak, jadi sangat memungkinkan apabila menerapkan strategi pembelajaran Problem Based Learning (PBL) yang didampingi oleh pendidik. Sehingga perkembangan peserta didik tidak hanya pada ranah kognif saja, tetapi juga ranah efektif dan psikomotorik. Pendidik juga harus memberikan estimasi waktu yang tidak terlalu lama sehingga peserta didik cenderung tidak bosan.

Strategi pembelajaran Problem Based Learning (PBL) telah menjadi strategi pembelajaran yang paling efektif untuk diterapkan sehingga menjadi solusi pembelajaran di dunia pendidikan. Faktanya, kampus dan sekolah terbaik di Singapura juga telah menerapkan strategi pembelajaran Problem Based Learning (PBL) begitu juga di Amerika, Inggris, Belanda, dan Australia. ${ }^{31}$

Sebagai pendamping strategi pembelajaran Problem Based Learning (PBL) dapat menggunakan bantuan media LCD proyektor untuk menampilkan videovideo animasi yang dirasa mampu menimbulkan pertanyaan dari peserta didik. Jika tidak memungkinkan menggunakan LCD proyektor pendidik dapat mengajak peserta didik untuk melakukan kegiatan pembelajaran out door. Belajar di taman bermain atau dengan memanfaatkan fasilitas yang ada. Maka dari itu, sebagai pendidik dituntut untuk kreatif dan inovatif.

\section{Catatan Akhir}

Media merupakan alat bantu yang digunakan untuk mempermudah komunikasi dengan orang lain. Media pembelajaran adalah alat yang digunakan pendidik untuk membantu menjelaskan isi dari materi yang disampaikan kepada peserta didik. Sementara itu, strategi pembelajaran merupakan suatu pendekatan pendidik terhadap penggunaan informasi, mulai dari pemilihan sumber belajar sampai dengan menetapkan peranan peserta didik dalam pembelajaran Pendidikan Luar Biasa (PLB) adalah salah satu pendidikan yang diberikan kepada anak berkebutuhan khusus. Dengan terwujudnya Sekolah Luar Biasa sebagai wadah untuk anak berkebutuhan khusus mendapatkan pendidikan yang sama dengan anak lainnya.

Pendidik harus kreatif dan teliti dalam menentukan media dan strategi yang digunakan dalam proses pembelajaran. Keduanya berperan sebagai instrumen pendukung dalam penyampaian materi pembelajaran. Penggunaan media dan strategi pembelajaran untuk anak berkebutuhan khusus menjadi aspek penting bagi pendidik dalam mencapai tujuan pembelajaran. Anak berkebutuhan khusus harus tetap dipandu secara langsung oleh pendidik. Oleh karena itu, model pembelajaran teacher centered learning tetap relevan dengan kondisi peserta didik. Untuk lebih mengoptimalkan proses pembelajaran, peneliti merekomendasikan agar pendidik di SLB Putera Asih Kediri menggunakan strategi pembelajaran Problem Based Learning (PBL). Dengan strategi ini, peserta didik akan terbiasa mencari solusi atas permasalahan yang mereka hadapi dalam kehidupan sehari-hari.

${ }^{31}$ Syaifulloh, "Pengaruh Strategi Problem-Based Learning (PBL) Terhadap Motivasi Dan Hasil Belajar Peserta Didik Pada Mata Pelajaran Fiqih Di Ma. Khozinatul “Ulum Blora Jawa Tengah,” 125. 


\section{Daftar Rujukan}

Abidin, Jam'ah. "Rancangan Strategi Pembelajaran." Jurnal Ilmiah Keislaman 12, no. 1 (2013): 9.

Amir, M.Taufik. Inovasi Pendidikan Melalui Problem Based Learning Bagaimana Pendidikan Memberdayakan Pemelajar di Era Pengetahuan. Jakarta: Kencana, 2009.

Andriani, Tuti. "Sistem Pembelajaran Berbasis Teknologi Informasi Dan Komunikasi," 2015, 24.

Dan, Tarbiyah, Keguruan Uin, dan Raden Fatah. "Implementasi Pendidikan Karakter Di Sekolah" 1 (2015): 19.

Dermawan, Oki. "Strategi Pembelajaran Bagi Anak Berkebutuhan Khusus Di SLB." Psympathic: Jurnal Ilmiah Psikologi 6, no. 2 (28 Februari 2018): 886-97. https://doi.org/10.15575/psy.v6i2.2206.

Fahdini, Reni, Ence Mulyadi, Deni Suhandani, dan Julia Julia. "Identifikasi Kompetensi Guru sebagai Cerminan Profesionalisme Tenaga Pendidik di Kabupaten Sumedang." Mimbar Sekolah Dasar 1, no. 1 (2014): 33-42.

Herman, Tatang. "Pembelajaran Berbasis Masalah untuk Meningkatkan Kemampuan Berpikir Matematis Tingkat Tinggi Siswa Sekolah Menengah Pertama," 2007, 10.

Kilroy, D A. "Problem Based Learning." Emergency Medicine Journal 21, no. 4 (1 Juli 2004): 411-13. https://doi.org/10.1136/emj.2003.012435.

Lidinillah, Dindin Abdul Muiz. "Pembelajaran Berbasis Masalah (Problem Based Learning)." Jurnal Edukasi: Jurnal Bimbingan Konseling 1, no. 2 (2010): 12.

Moleong, Lexy J. Metode Penelitian Kualitatif. Bandung: Remaja Rosdakarya, 2017.

Muhassin, Mohammad. "Peranan Pendidikan Luar Biasa Dalam Pembinaan Anak Tunagrahita: Studi pada Sekolah Luar Biasa (SLB) C Dharma Bakti Pertiwi Bandar Lampung," t.t., 18.

Oktorina, Fipta. "Peningkatan Prestasi Belajar Siswa Tuna Grahita Kelas VI SLB Negeri Kota Bengkulu Semester I Tahun Pelajaran 2016/2017 Pada Pembelajaran IPS Melalui Penggunaan Media Gambar" 16, no. 1 (2017): 17.

Pradana, Mochamad Desta. "Pengembangan Media Tutorial Mata Kuliah Media Fotografi Pembelajaran.” Edudeena 2, no. 1 (2018): 20.

Ruliansyah, Ruliansyah, Irfan Dwi Jaya, dan Septian Syaputra. "Aplikasi Pembelajaran Dasar Anak Retardasi Mental Berbasis Android (Studi Kasus: Sekolah Luar Biasa (SLB) C Karya Ibu Palembang)." JUSIFO (Jurnal Sistem Informasi) 3, no. 1 (30 Juni 2017): 73-80. https://doi.org/10.19109/jusifo.v3i1.3861.

Sanjaya, Wina. Strategi Pembelajaran Berorientasi Standart Proses Pendidikan. Jakarta: Prenada Media Group, 2010.

Sudarman. "Problem Based Learning: Suatu Model Pembelajaran untuk Mengembangkan dan Meningkatkan Kemampuan Memecahkan masalah." Jurnal Pendidikan Inovatif 2, no. 2 (t.t.): 10.

Sufirmansyah, Sufirmansyah. "Reaktualisasi Kurikulum Pendidikan Agama Islam Integratif (Telaah Kritis Komparatif di Pesantren, Sekolah, Dan Madrasah)." Realita 6, no. 2 (2018): 157-68.

Syaifulloh, Ahmad. "Pengaruh Strategi Problem-Based Learning (PBL) Terhadap Motivasi Dan Hasil Belajar Peserta Didik Pada Mata Pelajaran Fiqih Di MA. Khozinatul 'Ulum Blora Jawa Tengah.' Wahana Akademika: Jurnal Studi Islam dan Sosial 3, no. 2 (28 Desember 2016): 121. https://doi.org/10.21580/wa.v3i2.1148. 
Tarnoto, Nissa. "Permasalahan-Permasalahan yang Dihadapi Sekolah Penyelenggara Pendidikan Inklusi pada Tingkat SD.” Humanitas: Jurnal Psikologi Indonesia 13, no. 1 (2016): 50-61.

Telaumbanua, Tetema. "Pemanfaatan Media Pembelajaran dalam Pembelajaran Bahasa Inggris." Warta Darmawangsa, no. 48 (2016): 42-50.

Umar, Ninda Handayani Muniroh, Parmin Parmin, dan Indah Urwatin Wusqo. "Pengaruh Media Kartu Pintar Tumbuhan Berbasis Science Edutainment terhadap Minat Belajar dan Pemahaman Konsep Siswa Tema Gerak Tumbuhan." Unnes Science Education Journal 5, no. 2 (2016): 1288-97.

Widi, Narulita Anugrahing, dan Rullan Nirwansyah. "Penerapan Aksesibilitas pada Desain Fasilitas Pendidikan Sekolah Luar Biasa" 2, no. 2 (2013): 6.

Winaldi, Iman, dan Agus Setyawan. "Aplikasi Pengenalan Bahasa Isyarat Untuk Penyandang Tuna Tungu Berbasis Android (Studi Kasus : SLB Madina Serang)." JSiI Jurnal Sistem Informasi) 5, no. 2 (18 Oktober 2018). https://doi.org/10.30656/jsii.v5i2.779.

Zainuri, Ahmad. "Media Pembelajaran dalam Pandangan Islam." Medina-Te: Jurnal Studi Islam 14, no. 1 (16 Juli 2018): https://doi.org/10.19109/medinate.v14i1.2351.

Zamrony. "Arah Baru Pendidikan Islam: Membangun Epistemologi," t.t., 25. 